\title{
Bioelectric Energy Sources
}

National Cancer Institute

\section{Source}

National Cancer Institute. Bioelectric Energy Sources. NCI Thesaurus. Code C16339.

Implantable devices which convert biological energy (chemical energy of the metabolism

of continuously regenerating body fluids or mechanical energy of periodic movements)

to electrical energy. The sources include biogalvanic cells, biofuel cells, and ionic concentration cells. 